\title{
Originalartikel
}

\section{Staying alive?}

\section{Dealing with the uncertainty of childhood cancer}

Pia Løvschal-Nielsen ${ }^{1}$, Rikke Sand Andersen ${ }^{2}$ and Lotte Meinert ${ }^{3}$

${ }^{1}$ The Department of Anthropology, Faculty of Arts, Aarhus University, Aarhus pia.louschal-nielsen@webspeed.dk

${ }^{2}$ The Department of Anthropology, Faculty of Arts, and the Research Unit for General Practice, Faculty of Health, Aarhus University, Aarhus rsa@feap.dk

${ }^{3}$ The Department of Anthropology, Faculty of Arts, Aarhus University, Aarhus lotte.meinert@cas.au.dk

Løvschal-Nielsen, Pia; Andersen, Rikke Sand; Meinert, Lotte (2017). 'Staying alive? Dealing with the uncertainty of childhood cancer' i Tidsskrift for Forskning $i$ Sygdom og Samfund, nr. 27, 99-115.

This article explores how institutions and individuals in Denmark deal with the uncertainty of cancer in children. Based on a seven months ethnographic fieldwork conducted on a paediatric oncology ward during the period 2011-2013, the article examines how uncertainty manifests itself in the interface between cancer treatment and institutional childhood in the Danish welfare state. The argument is based on American pragmatist philosophy and its ideas about how people respond to a hazardous world in constant transformation. Through a focus on practices, the article explores how clinical and existential uncertainty arises for children and their families, and how they deal with this by navigating their way round the more tangible forms of insecurities. Important collective attempts to circumscribe clinical uncertainty are part of this navigation, but the article argues that epidemiologically based practices of dealing with the clinical uncertainty of cancer paradoxically gives rise to existential and social uncertainty for the affected children and their families, which they struggle with during treatment and even as long-term social effects into adolescence and 
young adulthood. The article suggests that more attention should be paid to assist children to manage the social and existential uncertainty that emerges in the interface between being a child in cancer treatment and being a child in the Danish welfare state.

\section{Introduction}

About a year ago, Leo, a boy of eleven years of age, was diagnosed with a tumour and has since been a cancer patient on the paediatric oncology ward, but now he is about to be discharged and attends the final network meeting ${ }^{1}$ together with his immediate family, some uncles and aunts, a physician and a nurse. The physician opens the meeting with a summary of Leo's medical trajectory and his current medical status and prospects. Leo's type of cancer seldomly returns, she says, because the treatment agenda that is used with this kind of cancer is known to be potent and successful. She also stresses that Leo was diagnosed and began treatment at an early stage of the disease, when his tumour was still minor, which has been a positive factor for the efficiency and outcome of the treatment. According to the physician, these factors together indicate a high degree of biomedical certainty, and she states that Leo's cancer has been treated successfully and that his treatment trajectory is a success. 'It's wonderful', , says Leo's father, and relieved bursts of laughter can be heard around the table, indicating that whatever disquiet the family might have experienced concerning Leo's cancer and future has vanished. In this joyful mood, the physician continues:

'The plan is that you come here for follow-ups for the next five years. The first three years, four times a year, and the last two years, twice a year. Your first follow-up is already in March, because we like to run the follow-up according to certain intervals's

In this brief presentation of the communication between a physician, a child and his family at the end of active cancer treatment, we can see how follow-up programs - within the logic of epidemiology and biomedicine - make sense as a way of controlling the imminent clinical uncertainty that lingers, even when cancer treatment has ended. Follow-up by follow-up, year after year, Leo must return until present guidelines and socially agreed upon parameters deem his risk of relapse - and thus the clinical uncertainty - insignificant. Frameworks and disease categories dictate appropriate treatment choices and are, as Rosenberg reminds us, social entities (Rosenberg, 2007:5). This also applies to cancer. How specific societies think of and react to cancer are the results of ongoing labratory processes, 
scientific meta-analysis and consensus-making; none of which provide neither certainty nor security (Keating \& Cambrosio, 2011). According to the philosopher Ian Hacking, statistics are methods, a 'style of reasoning', developed in order to explain specific problems through the analysis of regularities of populations and the calculus of probabilities, and they generate a particular kind of knowledge (Hacking 1992). Even though 'Leo's kind of cancer seldomly returns', as the physician says, absolute knowledge and clinical certainty does not exist. There is no way of really knowing whether 'follow-ups' are a way of managing the clinical uncertainty and the inability to foresee Leo's future, but on a general level, follow-ups are a means by which clinicians reduce clinical uncertainty, or, to use Hacking's term, by which they 'tame chance' (Hacking 1990).

When the physician presents the five-year follow-up plan, silence falls upon Leo and his family, probably indicating apprehension in the face of a prolonged engagement with treatment and the hospital. Follow-ups can tame chance and circumscribe clinical uncertainty, but at the same time they call attention to probability and risk, which means that the notions of relapse and death emerge with all of the existential uncertainty these entail, even after a successful cancer treatment. To Leo's family, the biomedical attempt to circumscribe clinical uncertainty emphasizes this existential uncertainty, highlighting that it will always prevail and will continue to feed the existential concerns about Leo's present and future. The case of Leo introduces the theme of this article - how uncertainty pertaining to cancer manifests itself and is dealt with through institutional and individual practices in particular contexts. We emphasize that attempts to create some measure of clinical certainty and security are important collective efforts. Yet, for children ${ }^{4}$ in cancer treatment on the Danish paediatric oncology ward, the overall clinical uncertainty of cancer creates experiences of uncertainty of an existential and social nature, which the children then have to deal with.

Breaking the silence that has fallen upon his family after the presentation of the follow-up program, Leo asks the physician if he can now go on vacation with his father. The question indicates what matters to Leo and what kind of uncertainty he finds important to deal with. In a recent review by the Danish Cancer Society, young Danish survivors of childhood cancer make explicit reference to experiences of social uncertainty in terms of a continuous struggle to keep in touch with friends and avoid social isolation (Kræftens Bekæmpelse, 2015). The review makes it clear that social and existential uncertainty matters greatly to the young interviewees. According to the anthropologist Whyte, what matter to people pertains to what they care about, and responding to uncertainty is an attempt to make 
more secure that which you can secure, which, in a pragmatist perspective and on the level of the individual actor, always takes the form of an engagement with the world, and, not least, depends on the available resources and people's access to them (Whyte, 2009). Whereas clinicians have access to a web of guidelines and socially agreed upon parameters to deal with the clinical uncertainty of cancer, we know little about how children deal with uncertainty, what matters to them and their families in the Danish welfare society when they are confronted with cancer, what measures they take to reduce the experience of uncertainty, and what resources, guidelines and parameters they turn to and have access to in this situation.

\section{Dealing with uncertainty}

We find theoretical inspiration in American philosophical pragmatism and its focus on practices and its ideas about the world as a place in constant flux and transformation, and as a place constructed on the basis of human interests and a view from somewhere, rather than from nowhere. The American philosopher John Dewey states that the world is hazardous and constantly shattered by unforeseen alien forces imposing themselves on people. Therefore, uncertainty is an inherent part of human experience. Yet, according to Dewey, certain conditions incite people to respond and to seek to circumscribe uncertainty through experimenting practices in order to attempt to create security (Dewey, 1929). Science, technology and social institutions are, according to Deweyans, empirical results of institutionalized attempts to circumscribe uncertainty and to pursue some measure of security (Whyte, 1997; Douglas, 2001), as is evident in the institutions of the Danish welfare state. Biomedicine's long-standing knowledge and tradition is another example of institutionalized attempts to circumscribe uncertainty. But when precariousness makes its presence felt, it changes and destabilizes people's experience of the world, often transforming it into an experience of being in a sea of unpredictability. Institutional attempts to circumvent the frightful atrocities of cancer, however, also result in a paradox: the many biotechnical interventions rationally designed to circumscribe clinical uncertainty may in turn give rise to new kinds of uncertainty (Steffen et al., 2005), including existential experiences. In order to explore such paradoxes we are inspired by the anthropologist Henrik Vigh's concept of 'social navigation' as a way of examining such experimental practices as they unfold in social and moral environments that are destabilized 
and turned into a maelstrom (Vigh, 2007; 2009). Social navigation directs attention to how people deal with uncertainty under changing circumstances, and how people move in relation to prospective positions, both in the present and in the near and distant future (Vigh, 2009: 424-425). A pragmatic approach means, Whyte argues, that we need to look at people as actors who attempt to alleviate suffering and uncertainty (Whyte, 1997:20-21). With this in mind, we explore how children and family members manage the intangible existential uncertainty of cancer by experimenting and acting on concrete hazards.

Based on seven months of ethnographic fieldwork conducted on a Danish paediatric oncology ward during the period 2011-2013, we draw on two cases - the girl Sophia and her mother Lisa, and Felix, a young teenage boy. Through a focus on these children's navigating practices, we focus on the manifestations of clinical and existential uncertainty in the interface of cancer treatment and childhood in the Danish welfare state. We explore how uncertainty manifests itself for these children and their families and how they deal with the paradox that emerges from being a child in cancer treatment in the Danish welfare state.

\section{Uncertainty as contingent upon context}

Dewey reminds us that uncertainty is generic and is an inherent experience everywhere, but he also states that uncertainty and socio-political settings are mutually established and therefore action is always situated within the wider context of social and moral issues (Boisvert, 1998:31), which makes uncertainty contingent upon context. When people in Uganda deal with misfortune, social relations and kinship are pivotal, linking their management of uncertainty to social and moral concerns (Whyte, 1997). In Botswana, citizens have free access to biomedical cancer treatment, yet, uncertainty emerges in the form of late diagnosis, expired medications, technology out of order, low blood supplies, few physicians and oncologists and people having multiple diseases (Livingston 2012), which link Botswanan management of uncertainty to a general lack of sufficient resources. In Argentina, biomedical knowledge, technology and medication are available, but only at urban hospitals. In the rural areas, long distances, poor infrastructure and scarce economic resources often prevent children and families from adhering to prescribed treatment trajectories at the urban hospitals (Vindrola-Padros, 2012). This links uncertainty to social and geographical inequality and inequity in health care. Dealing with the uncertainties of illness varies according to the contexts 
in which the illness is constituted and emerges (Lock \& Nguyen, 2010). Moreover, in the contexts described by Vindrola-Padros and Livingston above, cancer is associated with the certainty of death more than with the uncertainty of survival, which contrasts with how cancer statistics in welfare states articulate the issue as one of survival probability ${ }^{5}$. However, a recent study nuances cancer survival probability in the Danish welfare state by indicating that children from families with low income and short education are less likely to survive childhood cancer than children from families with more resources (Simoni et al. 2016) ${ }^{6}$. Another recent study has nuanced survival probability by pointing out that the number of children and young people with cancer is unknown in many low-income and middle-income countries where data on cancer incidence are not collected (Steliarova-Foucher et al. 2017). These studies thus emphasize that the uncertainty pertaining to cancer and the probability of survival relates to people's socio-economic position, even within the Danish welfare state where equality and equity are key socio-political aims.

\section{Cancer treatment and childhood in the Danish welfare state}

The Danish welfare state developed during the latter half of the twentieth century. Based on a social democratic model, its main purpose is to ensure high levels of social equality and security. This is achieved by a taxation system that redistributes the financial means through public welfare institutions and by offering benefits in times of misfortune, such as unemployment, disability and illness (Einhorn \& Logue, 2003). Public healthcare is a core welfare institution to which all residents of Denmark have free access, including hospital care, through a referral from a general practitioner. Medicines are co-paid but hospital services are free at the point of use (Pedersen, Andersen \& Søndergaard, 2012). Concerning children, a 'care partner', often a parent, is co-admitted and his or her income is reimbursed by the state during the hospitalisation and treatment period. Cancer in children is managed by specialised staff in paediatric oncology centres located at the public hospitals. Modalities and treatment agendas are accredited procedures, and almost all refer to international cancer treatment protocols (Dansk Børnecancer Register, 2016). Biomedical treatment modalities often consist of different therapies, such as chemotherapy (cytostatic), surgery and radiation. Generally, most 
children are given intensive chemotherapy, also when the treatment consists of a combination of two types of modalities (American Cancer Society, 2014), which is also the case in the Danish ward. Here, the treatment process is coordinated with each individual child and his or her specific diagnosis and response to treatment, and is, if necessary, adjusted or substituted with another treatment agenda during the treatment process. During treatment, children are also given other kinds of medications to alleviate pain and the common side effects, such as fatigue, nausea, diarrhoea or constipation, irritation and sores in the mouth, headaches, loss of appetite, hair- and weight loss and a delayed growth (Bryant, 2003). Cancer treatment procedures, medications and side-effects drain children of energy and one of the modalities, chemotherapy, is highly toxic and destroys the immune system, which means that children are extremely susceptible to contagions from other human beings during treatment. An otherwise relatively harmless infection may therefore turn into a fatal condition within a short time. Controlling and managing such concrete risks and insecurities are therefore an integrated part of cancer treatment. Likewise, children and their families are strongly recommended to restrict sociability also at home ${ }^{7}$ and refrain from visiting enclosed and crowded indoor places during treatment, such as malls, sports centres as well as day care and educational institutions.

Alongside the Danish health care institutions, the day care and educational institutions for children and young people are also central to the welfare state. Day care is a common experience for children across Europe, and in Denmark 87 per cent of one-year-old children, 93 per cent of two-year-olds, and 97 per cent of children between three and five spend their daytime in day care institutions (Gilliam \& Gulløv, 2014). Moreover, childhood is, argues Gulløv, loaded with moral opinions about the nature of the child, about the best circumstances in which to grow up, what virtues a child should have in the Danish welfare state, and which knowledge and abilities are required for a future considered successful by society (Gulløv, 2011). Langer and Højlund link this socially shaped institutional trajectory to 'well-faring' in a relatively stable landscape, a relationship that mutually shapes the well-farer and his or her surroundings (Langer \& Højlund, 2011:1-2). Institutionalised well-faring is how the welfare state seeks to socialise its young citizens, even out social inequalities and make childhood a secure experience while also creating future residents for the welfare state. Although it is a matter of some dispute and some families and individuals break with this institutionalised childhood and its many cultural and normative connotations, manuscripts, virtues and 
visions for the good life, it is the ordinary trajectory for most Danish children (Gilliam \& Gulløv, 2014). It provides, moreover, a social safety net for these children.

The other safety net, the health system, is brought in in those tragic cases where cancer strikes. This is a safety net on which children's lives depend during treatment. A cancer treatment trajectory is a radical digression from an ordinary Danish childhood trajectory. Whereas the social segregation recommended as part of the treatment may strengthen the children's recovery trajectory and enhance their possibilities of survival and of securing a future, the social segregation departs from the moral virtues embedded in well-faring, such as how to be a child and achieve the abilities that are required in order to become a future resident in the Danish society. In Dewey's terms, we may understand cancer treatment and wellfaring as opposing forces that fling children and their families into a paradoxical sea of uncertainty. With no maps to help them cross this forceful and dangerous sea of uncertainty, advanced navigation skills are called for.

\section{Navigating between medical and social hazards}

Sophia enrols as an 8-year-old in a cancer treatment program. She and I meet almost every time she is admitted to the ward for a therapy course. It is easy to get in contact with Sophia and her co-admitted mother Lisa. On the ward, many children stay in their private rooms and watch TV to alleviate tribulations and disquiet from the therapy, but not Sophia and Lisa who spend as little time as possible in their private room. During our encounters on the ward, we share whatever stories we can, for example about pets and their escapades. During our talks, Sophia and especially Lisa highlight how they attempt to be active at home, doing handicrafts, baking and taking bicycle trips to a nearby forest and farm. Being outdoors, active, and social is a set of values that Lisa repeatedly emphasizes verbally, and which Sophia practices as soon as she begins to recover from the therapy courses on the ward. She then usually engages in some kind of handicraft activity, attends school classes and participates in children's events on the ward. After the summer, half a year on from our first encounter and a little more than a year after Sophia has started treatment, I visit her and Lisa in their home. Arranging this visit has taken some time and negotiation, but eventually we have agreed on a date, time and length for the visit. Soon after I arrive at their home, Lisa starts to talk about the ever-present risk of contagion and how it has socially isolated Sophia and the family for a long time, and she compares it to being in prison: 
'It's like being imprisoned. You cannot go out, because outside the house there are dangerous bacteria ${ }^{8}$

The 'incarceration' is meant to protect Sophia against contagion, because cancer has made human beings dangerous to her. Lisa is very concerned about bacteria and the risks these might pose to Sophia. 'They are unknown bacteria', Lisa says, more specifically referring to people this time. Her concern about bacteria is mirrored in a homemade sticker I noticed on arriving at their home. Already on the doorstep, Lisa attempts to prevent human bacteria 'from outside the house' from getting into the house and into Sophia's body. The sticker on the front door is a reminder to whoever enters through that door, asking in capital letters: 'DID YOU DISINFECT YOUR HANDS?'10

Lisa's attempts to create some measure of security for Sophia by keeping her from encountering other people, especially at crowded indoor spaces and the long-term social segregation combined with the fear of infection has made it difficult for Sophia and Lisa to live up to their own desires and ideals about being social. But as we sit at the kitchen table and start to browse photos on Sophia and Lisa's cell phones, I notice photos of the two of them among other people on a campsite. It turns out they stayed in a caravan on this campsite for some weeks during the summer when Sophia was still in treatment. When I ask about this, Lisa explains what it meant to them:

'It was so amazing, because until then Sophia had only been with sick children in the hospital, and ... here, we were out in the world. And then, an ordinary and healthy child asks to play with Sophia, and you can agree to it, because it takes place on a campsite. It was really so amazing. We had almost forgotten what it was like to escape out into freedom, but that's what we did, right there'11.

To Lisa and Sophia, bacteria may pose a risk to Sophia's life anywhere, but especially around people in crowded indoor places. Managing these invisible but everpresent risks, they have complied with medical advice. So far, they have stayed away from other people, asked visitors to disinfect their hands, and remained mainly within their private home with only the occasional trip to outdoor areas where they can spend time with no-risk animals, rather than with people, all in order to attempt to manage the uncertainties pertaining to Sophia's health situation. However, complying with these medical guidelines means that the highly valued virtues of being social and having friends have been sidetracked altogether.

Sociability, or rather the absence of it, is a concern to many children and parents on the ward. 'It's hard to watch when your child gets fewer and fewer text messages'12, 
the mother of a teenager says to me. Lacking a social life is not a concern reserved for mothers, also 14-year-old Felix is concerned about friends, their genuineness and whether he will lose them or not. He is temporarily back on the ward due to a sudden infection and this time sits isolated in a private room. Felix does not talk much about his cancer or treatment, but he reflects on the fact that some of his family members have previously died from cancer, leaving other family members alone, 'sitting by themselves in a big house', as he says. In these reflections, uncertainty emerges as the risk of death, but also as the risk of loneliness. Relationships and friends soon become the main issue during our conversation and Felix talks about keeping in touch, the essence of true friendship, having or not having friends, and how you can be certain about who your friends are. He talks about how he attempts to maintain social relationships with friends and schoolmates and how he keeps in touch with them through social media. When I ask him to tell me about what he did yesterday on the ward, he says:

'Well, I sort of slept most of the afternoon, because I'm basically tired from this [infection], and then, well, then I sat by my computer, for the rest of the evening actually. And you're on, and then you watch a bit of $T V$, and then you just keep it [the computer] running all the time'. .... 'On Facebook you can see what the others are doing, and I can also write to them and talk with them. I brought my headset, you see, and then I can talk with them on Skype. ${ }^{13}$

This is the way he keeps himself updated he says, and 'the others' whom Felix refers to are his friends at home. While isolated on the ward, Felix maintains his social network by chatting and keeping up with friends through social media. Although he can look at uploaded videos from a party at school, look at what his friends are doing and saying, and keep updated with them on the social media, he cannot participate, he says, and he expresses concern about the quality of this sort of relationship with his friends. During the interview, he repeatedly reflects on how easily he might lose touch with friends and who his 'true' friends are.

'When I was in [a hospital he was admitted to previously], that's when I found out who my true friends were - who kept in touch and who just kept a distance. Many sent letters and the like, and then I just knew that those who did were the ones who wanted to get involved, and those who didn't, they were just - well, it didn't matter then. And they [the true friends] sent letters all the time. And they were the ones I talked with over there [at the other hospital]. ${ }^{14}$

The experience of losing friends may be the reason why he agrees to friends visiting him at home, although from a medical perspective such encounters pose a 
potential hazard to him. But Felix deals with this by navigating his way round the issues of proximity and space in his own way:

'... Well, actually, we often go for walks at night. So, if we sit, if I sit in my room and we talk on Skype or something like that, then I ask them if they'd like to go for a walk. And then we often walk a particular route. We actually do that almost each night when we're at home. It also does me good - that I get out and about like that. ${ }^{15}$

Clinicians focus on responding to clinical uncertainty through treatment, followups and social segregation. For Felix and Sophia, cancer has destabilised the ordinary world, transformed it and turned it into a sea of uncertainty, and they respond to this uncertainty by navigating the hazards about which they can do something, experimenting and looking for possibilities. When Felix keeps in touch with friends through social media he complies with the medical guidelines of keeping a safe social distance and controlling the risk of contagious infections this way; yet, what matters to Felix is to maintain friendships by being with friends the 'ordinary' way, i.e. meeting them in real life. From a biomedical perspective, indoor encounters are unsafe, because they are a serious risk to Felix and Sophia's lives, and thus Felix arranges to stroll the neighbourhood streets with friends, and Sophia and Lisa choose to spend some days in a caravan on a campsite. By shifting their social life to the outdoors, a campsite and the neighbourhood streets, these children navigate between medical and social hazards in order to secure both the physical and social present and future. In destabilised and transformed worlds, people navigate and look for possibilities in the present and the future (Vigh, 2007, 2009), and by navigating between hazards children and their families find possibilities that provide them with the experience of safety while at the same time staying alive socially.

\section{Staying alive?}

In a recent study by the Danish Cancer Society, young Danish 'survivors of childhood cancer' describe concerns about the long-term effects of cancer treatment. Now young adults, most of the interviewees express that they continue to experience a loss of friendships, a sense of social isolation and not belonging to a group and of not being able to participate in social events, because they find that cancer has in some ways changed their social resources and selves (Kræftens Bekæmpelse, 2015). The report is sustained by research focusing on survivors of child- 
hood cancer, which documents that, while the overall survival increases in welfare states, the survivors continue to struggle with a decrease in social contact to friends. Compared to healthy peers, they spend more time on their own, and they often live at home or alone (Maurice-Stam, Grootenhuis, Caron \& Last, 2007). The studies indicate that survivors struggle to stay alive socially, as human beings, and that the cancer stalls their anticipated progress in life even after they have overcome treatment.

Institutionalized Danish childhood (Gilliam \& Gulløv 2014) and the sheltered social trajectory along which children move in accordance with a prescribed course toward a given future within the welfare society, termed well-faring by Langer and Højlund (2011), obviously does not guarantee opportunities for progress or an easy life. Each generation and era has its own particular challenges, and contemporary children and youngsters are most likely to experience existential uncertainty even within the frames of well-faring. But that lies beyond the scope of this article. However, cancer constitutes a set of circumstances of human existence wherein uncertainty concerning existence and future tend to concentrate and become critical, and we suggest that this effect is increased when children's well-faring is stalled by the social isolation recommended during treatment. We may understand this as barring children from opportunities to progress or succeed in life along the expected life courses, which Vigh states may result in a state of 'social death' and 'social moratorium' (Vigh, 2007:110-112). When children contract cancer, Danish health care institutions take most of the possible measures in order to ensure successful treatment and thereby the children's survival. This can be seen in the form of statements by Danish health promoters of cancer as an 'acute' disease, which changed the temporal organisation and rationales of cancer diagnostics (Tørring, 2013, 2014), and it can be seen in the form of accredited guidelines, follow-up programs, applying sufficient technology, free access to treatment and in the social segregation during treatment in order to circumscribe risks. Although such precautions may improve survival rates in general, they cannot make the individual child's survival certain. Survival is prioritized, but uncertainty prevails. Both of the two welfare systems deal with securing children's lives, but they do so in different ways, and for children in treatment (and their families) this results in a paradox. While it is necessary during treatment to take measures against the threats posed by social contacts in order simply to ensure the children's survival, these biomedical steps obstruct their access to childhood institutions and thus prevent their ability to stay alive socially and in terms of well-faring. As displayed in the cases described here, children and their families 
deal with this experienced paradox by finding creative and pragmatic ways of navigating these hazards. Felix and Sophia attempt to navigate their way out of a stalled existence by re-imagining and re-inventing unique practices that steer clear of threats that lurk like icebergs in the ocean, thus transiently moulding their experiences of uncertainty into experiences of well-faring and of staying alive. Transiently maybe, but perhaps long enough to have these children move along and stay alive, both during treatment and in the future. Navigation is, argues Vigh, a way out of an uncertain and stalled existence (Vigh, 2007:110-112).

This brings us to a final reflection on practicalities; why focus on how people navigate their way round these insecurities? Because certainty is an illusion and chance and failure are fundamental parts of action and of trying (Dewey, 1929), even within biomedical and welfare frameworks. Children deal with 'social death' in the form of blocked access to friends and to the virtues of well-faring. And whereas uncertainty remains abstract, it can be responded to by dealing with concrete hazards, and whereas uncertainty is likely to prevail or emerge in new shapes and forms, the experience of uncertainty can be moulded by means of navigating one's way round more specific and tangible threats. The young Danish survivors' narratives illustrate how uncertainty emerges in new guises after treatment. As in the case of Leo, the end of cancer treatment and follow-ups may be the way clinicians control the eminent clinical uncertainty, but for many children, there are no clear routes that will fully guide them in relation to their continued social existence after survival.

Whereas the Danish welfare society devotes a great many resources to children's cancer treatment and well-faring, little attention is paid to the paradox that children with cancer experience and to how they navigate their way across this dark ocean to stay alive, both in the present and in the near and distant future. Parents and children's attempts to deal with the paradox of uncertainty through navigating hazards demand a lot of surplus energy and resources from the children and families in question, resources that not everyone in the Danish welfare society has equal access to. Vast amounts of welfare resources are dedicated to cancer treatment, modalities and the continuous building of institutional knowledge, and the value of this is indisputable. But along with contemporary research on young cancer survivors (e.g. Kræftens Bekæmpelse, 2015, Maurice-Stam, Grootenhuis, Caron \& Last, 2007; Stein, Syrjal \& Andrykowski, 2008; Guerny et al., 2009), and the fact that these children's lives continue to be fraught with the uncertainties that come with cancer, even long after successful treatment has been completed, and the fact that this has a significant - and potentially devastating - effect on 
their social lives, this article suggests that more resources and knowledge building should be devoted to assist children in constructing a socially sustainable existence during treatment. Staying alive is not merely a medical or physical issue; it is to a very large extent also a social issue.

\section{Noter}

1 Network-meetings are meetings held on the ward at the beginning, middle and end of a child's treatment. At the meeting clinicians inform a gathering of people, such as extended family, relatives, school friends, acquaintances, neighbors, teachers etc., invited by the child and his or her immediate family, about the child's diagnosis, medical trajectory plan, results and prospects and regulations for social encounters.

2 In Danish: 'Det er dejligt'

3 In Danish: 'Planen er, at du skal komme ind til opfølgning de næste fem år. De første tre år er det fire gange om året, og de sidste to år er det to gange om året. Din første opfølgning er allerede i marts, for vi vil gerne have, at opfølgningerne følger et bestemt interval'

${ }^{4}$ Children in cancer treatment on the paediatric oncology ward were between 0-15 years. In the following they are all referred to as 'children', regardless of age.

${ }^{5}$ From 1995-2002 the overall 5-year survival probability for children (age 0-14) is 81 percent in Europe (Kaatsch, 2010).

${ }^{6}$ In the article it is noted that most estimates in the crude analysis of the study did not reach statistical significance, yet a better survival rate for cancer in childhood was associated with parents with a higher education, higher maternal age and income, parents living together, and no siblings in the family (Simoni et al., 2016).

${ }^{7}$ Children and their families are recommended to ask about the health condition of people coming to visit them at home, as well as they are advised not to visit indoor areas in which the risk of contamination from other human beings is enhanced.

${ }^{8}$ In Danish: 'Det er ligesom at være i fængsel. Man kan ikke gå ud, fordi uden for huset er der farlige bakterier'

${ }^{9}$ In Danish: 'De er ukendte bakterier'

${ }^{10}$ In Danish: HAR DU SPRITTET DINE HÆNDER?

11 In Danish: 'Det var helt fantastisk, fordi indtil da havde Sophia jo kun været sammen med syge børn på hospitalet, og ... her var vi ude i verden. Og så kommer der et helt almindeligt barn og vil gerne lege med Sophia, og man må godt sige ja, fordi det er på en campingplads. Det var virkelig helt fantastisk. Vi havde næsten glemt, hvordan det var at slippe ud i friheden, men det var altså lige der, vi gjorde det'.

${ }_{12}$ In Danish: 'Det er svært at se på, hvordan ens barn får færre og færre sms'er'

${ }^{13}$ In Danish: 'Jamen jeg sov sådan set det meste af eftermiddagen, fordi jeg er bare træt af, at jeg har den der [infektion] og så, ja, så sad jeg ved min computer. Det gjorde jeg sådan set resten af aftenen. $\mathrm{Og}$ så sidder man ved den, og så ser man lidt fjernsyn, og så har man den bare til at stå hele tiden ... På Facebook, så kan man jo se, hvad de andre laver. 
og jeg kan også skrive med dem, og snakke med dem. Jeg har jo mit headset med, og så kan jeg jo sidde og snakke med dem over Skype'

14 In Danish: 'Da jeg var på [et andet hospital], da fandt jeg jo ud af, hvem der var mine rigtige venner - hvem der holdt kontakt til mig, og hvem der bare blev væk. Der var mange, der sendte breve og sådan, og så vidste jeg jo bare, at dem der gjorde det, var nogle, der ville have med mig at gøre, og dem der ikke gjorde, de var bare - det kunne jo bare være lige meget så. Og de [rigtige venner] sendte breve hele tiden. Og det var dem jeg snakkede med derovre [det andet hospital]'

${ }^{15}$ In Danish: 'Ja men, vi er egentlig sådan tit ude og gå om aftenen. Så hvis vi sidder, hvis jeg sidder nede på mit værelse, og vi snakker over Skype og sådan noget, så spørger jeg dem, om de vil med ud og gå. Og så er det tit, at vi har sådan en rute, vi går. Det gør vi sådan set næsten hver aften, når vi er hjemme. Det er jo også meget godt for mig - at jeg kommer ud og rører mig og sådan noget'.

\section{Acknowledgements}

This article is part of a PhD study, which is partially funded by 'Helsefonden'. Grant no. 2011B085.

\section{References:}

American Cancer Society (2014). Cancer Facts \& Figures 2014. Special Section: Cancer in Children \& Adolescents (pp. 25-43). Atlanta: American Cancer Society. (Accessed June 25th 2015)

Boisvert, R.D. (1998). Chapter 2: Thinking. In: R.D. Boisvert, John Dewey: Rethinking Our Time. Albany, NY: State University of New York Press, pp 29-48

Bryant, R. (2003). Managing side effects of childhood cancer treatment. J Pediatr Nurs. Vol.18, 113-125, DOI:10.1053/jpdn.2003.11, doi.org/10.1053/jpdn.2003.11

Dansk Børnecancer Register (2016). National Årsrapport 1985-2015 [Danish Register of Cancer in Children (2016): National Annual Report 1985-2015]. Aarhus: KEA, Aarhus University. http://www.kea.au.dk/da/kliniskkvalitet/kliniske-databaser/B\%C3\%B8rnecanc erRegister.html (accessed February 2nd, 2016)

Dewey, J. (1929). The Quest for Certainty. A Study of the Relation of Knowledge and Action. New York: Minton, Balch \& Company

Douglas, M. (2001). Dealing with Uncertainty. Ethical Perspectives. Vol. 8(3), 145-156, doi: 10.2143/EP.8.3.583185

Einhorn, E.S. \& Logue, J. (2003). Modern Welfare States: Scandinavian Politics and Policy in the Global Age. Westport and London: Praeger

Gilliam, L. \& Gulløv, E. (2014). Making children 'social': Civilising institutions in the Danish welfare state. Human Figurations: Long-term perspective on the human condition. Vol. $3(1)$ 
Guerny, J. C., Krull, K. R., Kadan-Lottick, N., Nicholson, H. S., Nathan, P. C., Zebrack, B. \& Ness, K. K. (2009). Social outcomes in the childhood cancer survivor study cohort. Journal of Clinical Oncology, 27, 2390-2395, doi: 10.1200/JCO.2008.21.1458

Gulløv, E. (2011). Welfare and Self Care: Institutionalized Visions for a Good Life in Danish Day-care Centres. Anthropology in Action. Vol. 18(3), 21-32, doi:10.3167/aia.2011.180303

Hacking, I. (1992). 'Style' for historians and philosophers. Studies in History and Philosophy of Science. Vol 23(1): 1-20. https://doi.org/10.1016/0039-3681(92)90024-Z

Hacking, I. (1990). The Taming of Chance. Cambridge: Cambridge University Press. https:// doi.org/10.1017/CBO9780511819766

Kaatsch, P. (2010). Epidemiology of childhood cancer. Cancer Treatment Reviews. Vol. 36, 277285, doi.org/10.1016/j.ctrv.2010.02.003

Keating, P. \& Cambrosio, A. (2011). Cancer on Trial: Oncology as a New Style of Practice. Chicago: University of Chicago Press

Kræftens Bekæmpelse (2015). At overleve kræft som barn har konsekvenser for resten af livetogså selv om man ikke kan se det. [Surviving Cancer as a Child has consequences for the remainder of life - even if one cannot see it]. The study is available in Danish at: https:// www.cancer.dk/dyn/resources/File/file/8/5138/1448010192/at_overleve_kraeft_som_ barn_rapport_hjemmeside.pdf (Accessed August 29th 2016)

Langer, S. \& Højlund, S. (2011). An Anthropology of Welfare: Journeying towards the Good Life. Anthropology in Action. Vol. 18(3), 1-9, doi:10.3167/aia.2011.180301

Livingston, J. (2012). Improvising Medicine: An African Oncology Ward in an Emerging Cancer Epidemic. Durham, N.C.: Duke University Press. https://doi.org/10.1215/9780822395768

Lock, M. \& Nguyen, V. (2010): An Anthropology of Biomedicine. Malden \& Oxford: Blackwell Publishing

Maurice-Stam, H., Grootenhuis, M.A., Caron, H.N. \& Last. B.F. (2007). Course of life of survivors of childhood cancer is related to Quality of Life in young adulthood. Journal of Psychosocial Oncology, 25(3), 43-58, doi.org/10.1300/J077v25n03_03

Pedersen, K.M., Andersen, J.S., \& Søndergaard, J. (2012). General Practice and Primary Health Care in Denmark. Journal of the American Board of Family Medicine. Vol. 25, Supplement, 34-38, doi:10.3122/jabfm.2012.02.110216

Rosenberg, C.E. (2007). Our Present Complaint: American Medicine, Past and Present. Baltimore, MD: The Johns Hopkins University Press

Simoni, S.B., Lund, L.W., Erdmann, F., Andersen, K.K., Winther, J.F., Schüz, J., Johansen, C., Schmiegelow, K. \& Dalton, S.O. (2016). Effect of socioeconomic position on survival after childhood cancer in Denmark. ACTA ONCOLOGICA. Vol. 55 (6), 742-750, doi.org/ 10.3109/0284186X.2016.1144933

Steffen, V., Jenkins, R. \& Jessen, H. (2005). Matters of life and death. In: Steffen, V., Jenkins, R. \& Jessen, H. (eds.): Managing Uncertainty: Ethnographic Studies of Illness, Risk and the Struggle for Control. Copenhagen: Museum Tusculanum Press, pp. 9-31

Stein, K.D., Syrjal, K.L., \& Andrykowski, M.A. (2008). Physical and Psychological LongTerm and Late Effects of Cancer. Cancer, Vol. 112(11), 2577-2592, doi: 10.1002/cncr.23448

Steliarova-Foucher, E., Colombet, M., Ries, L.A.G., Moreno, F., Dolya, A., Bray, F., Hesseling, P., Shin, H.Y., Stiller, C.A., and the IICC-3 contributors (2017). International incidence of childhood cancer, 2001-10: a population-based registry study. Lancet Oncol, Vol. 18:71931, doi.org/10.1016/S1470-2045(17)30186-9 
Tørring M.L. (2014.). Hvorfor akut kræft? Et bud på en epidemisk forståelse af tid og kræfttendenser i Danmark. Tidsskrift for forskning i sygdom og samfund, nr. 20, 13-45 [Why acute cancer? An estimate of an epidemic understanding of tendencies of time and cancer in Denmark. Journal of research in illness and society, no. 20, 13-45]

Tørring, M.L., Frydenberg, M., Hansen, R.P., Olesen, F. \& Vedsted, P. (2013). Evidence of increasing mortality with longer diagnostic intervals for five common cancers: A cohort study in primary care. European Journal of Cancer, 49(9), 2187-2198, doi.org/10.1016/j. ejca.2013.01.025

Vindrola-Padros, C. (2012). The Everyday Lives of Children with Cancer in Argentina: Going Beyond the Disease and Treatment. Children \& Society. Vol. 26(6), 430-442, doi: 10.1111/j.1099-0860.2011.00369.x

Vigh, H. (2009). Motion squared. A second look at the concept of social navigation. Anthropological Theory. Vol. 9(4), 419-438, doi: 10.1177/1463499609356044

Vigh, H. (2007). Navigating Terrains of War. Youth and Soldiering in Guinea Bissau. New York and Oxford: Berghahn Books

Whyte, S.R. (1997). Questioning misfortune. The pragmatics of uncertainty in eastern Uganda. Cambridge: Cambridge University Press

Whyte, S.R. (2009). Epilogue. In: L. Haram. \& C.B. Yamba (Eds.), Dealing with uncertainty in contemporary African lives (pp. 213-216). Uppsala: Nordiska Afrikainstitutet. 